\title{
REVISED A refinement to the formalin test in mice [version 2;
}

\section{peer review: 2 approved]}

\section{Douglas M Lopes (iD), Heather L Cater ${ }^{2}$, Matthew Thakur ${ }^{1}$, S.E. Wells², Stephen B McMahon ${ }^{1}$}

${ }^{1}$ Neurorestoration Group, Wolfson Centre for Age-Related Diseases, King's College London SE1 1UL, London, UK

${ }^{2}$ MRC Harwell Institute, Harwell Campus, Didcot, Oxfordshire, OX11 ORD, UK

V2 First published: 20 Jun 2019, 8:891

https://doi.org/10.12688/f1000research.18338.1

Latest published: 02 Aug 2019, 8:891

https://doi.org/10.12688/f1000research.18338.2

\section{Abstract}

The constant refinement of tests used in animal research is crucial for the scientific community. This is particularly true for the field of pain research, where ethical standards are notably sensitive. The formalin test is widely used in pain research and some of its mechanisms resemble those underlying clinical pain in humans. Immediately upon injection, formalin triggers two waves (an early and a late phase) of strong, nociceptive behaviour, characterised by licking, biting, lifting and shaking the injected paw of the animal. Although well characterised at the behaviour level, since its proposal over four decades ago, there has not been any significant refinement to the formalin test, especially those combining minimisation of animal distress and preservation of behavioural outcomes of the test. Here, we propose a modified and improved method for the formalin test. We show that anaesthetising the animal with the inhalable anaesthetic sevoflurane at the time of the injection can produce reliable, robust and reproducible results whilst animal distress during the initial phase is reduced. Importantly, our results were validated by pharmacological suppression of the behaviour during the late phase of the test with gabapentin, the anaesthetic showing no interference with the drug. In addition, we demonstrate that this is also a useful method to screen for changes in pain behaviour in response to formalin in transgenic lines.

Keywords

Pain, Formalin, Nociception, Behaviour, Refinement, 3Rs

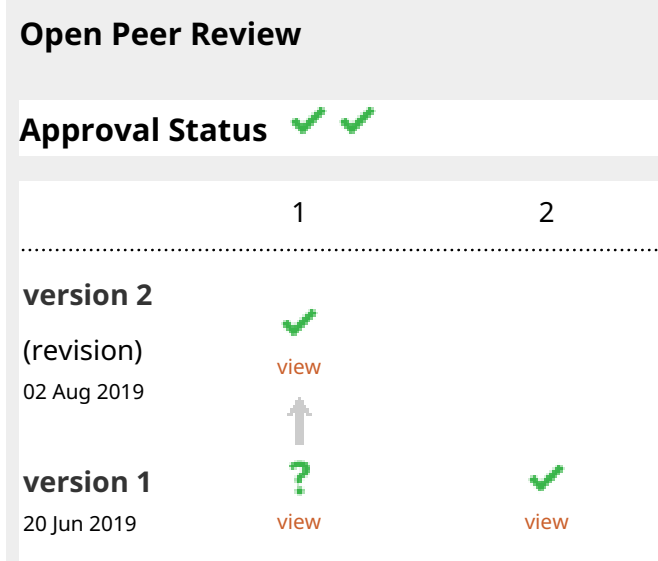

1. Nora Bourbia (ID), Public Health England, Chilton, UK

2. John Riddell, University of Glasgow, Glasgow, UK

Andrew Todd, University of Glasgow, Glasgow, UK Any reports and responses or comments on the article can be found at the end of the article. 
Corresponding author: Douglas M Lopes (douglas.lopes@kcl.ac.uk)

Author roles: Lopes DM: Data Curation, Formal Analysis, Investigation, Methodology, Visualization, Writing - Original Draft Preparation, Writing - Review \& Editing; Cater HL: Data Curation, Formal Analysis, Investigation, Methodology, Project Administration, Visualization, Writing - Review \& Editing; Thakur M: Data Curation, Formal Analysis, Investigation, Methodology, Project Administration; Wells SE: Conceptualization, Data Curation, Funding Acquisition, Investigation, Methodology, Project Administration, Resources, Supervision, Visualization, Writing - Review \& Editing; McMahon SB: Conceptualization, Funding Acquisition, Investigation, Methodology, Resources, Supervision, Visualization, Writing - Review \& Editing

Competing interests: No competing interests were disclosed.

Grant information: This work was supported by the Wellcome Trust [102645]; Medical Research Council [53658, 53650]. The funders had no role in study design, data collection and analysis, decision to publish, or preparation of the manuscript.

Copyright: ( 2019 Lopes DM et al. This is an open access article distributed under the terms of the Creative Commons Attribution License, which permits unrestricted use, distribution, and reproduction in any medium, provided the original work is properly cited.

How to cite this article: Lopes DM, Cater HL, Thakur $\mathrm{M}$ et al. A refinement to the formalin test in mice [version 2; peer review: 2 approved] F1000Research 2019, 8:891 https://doi.org/10.12688/f1000research.18338.2

First published: 20 Jun 2019, 8:891 https://doi.org/10.12688/f1000research.18338.1 


\section{REVISED Amendments from Version 1}

Following the reviewer's comments, to which we were very grateful for, we uploaded a new version addressing all their comments and suggestions. In summary, we conducted statistical tests comparing males and females across the different experiments and observe no differences between the genders. A sentence stating the above findings and a link to the Supplementary Figure containing further details on this has been added to the Material and methods section. The raw data containing the sex of each individual animal used was also uploaded to the supplementary information.

We added the specific background in which the C57/BL6 animals were bred on and we also addressed the comments on the different response of a specific control group in relation to the other groups - a paragraph was added to the manuscript pointing out the differences observed and explaining it. Re this experiment unfortunately, this line is no longer promptly available (it has been cryopreserved and archived) and therefore we are regrettably unable to repeat these experiments as suggested by one of the reviewers. Furthermore, an explanation as to why those specific transgenic mouse lines were chosen has been added to the Experimental Animals section. All other minor points (typos and verb tense) raised by the reviewer were also addressed.

See referee reports

\section{Introduction}

Since first reported over 40 years ago, the formalin test ${ }^{1}$ has been widely used in pain research and is known to capture mechanisms that are likely to be relevant to many pain patients in clinic $^{2,3}$, including the poorly localized, burning and throbbing pain sensation ${ }^{4}$. The unique feature of the formalin test is that it triggers two phases of nociceptive behaviour: the first one is directly linked to the stimulation of primary sensory neurons and is followed by a second phase, which is associated with inflammation and involves central sensitisation ${ }^{1,5-7}$. These phases are marked by striking pain behaviour in which the animals lick, bite, lift and shake the injected paw. Over many years, different groups have extensively characterised the test, demonstrating robust and reproducible quantitative behaviour outcomes $^{5,8-12}$.

The constant refinement of experimental procedures involving animals is important for the whole research community but is particularly important for the field of pain research, due to the obvious ethical implications of this type of research. Regulations regarding the use of animals for research in the UK dates back to the 19th century, with strict safeguards to avoid or minimise animal suffering and cruelty, as well as ensuring high animal welfare standards are met $^{13,14}$. Furthermore, the $3 \mathrm{Rs}$ concept (reduce, refine and replace) ensures that for every experiment, the use of animals is absolutely necessary ${ }^{13,15-17}$. Further to these ethical considerations, and of particular relevance to the formalin test, other evidence suggests that restraining also induces stress, behavioural and other physiological changes in the animals ${ }^{18-25}$, including hyperalgesia ${ }^{26-28}$, which can impact the outcome of the test. As highlighted in the above guidelines and given the current standard procedure for the formalin test, where the animals are physically restrained and may experience unnecessary levels of stress, the present study aimed to refine the current method used for the injection of formalin, without compromising its reproducibility. We posed the question of whether anaesthetising the animal at the time of formalin injection could result in more consistent injections and reduce the stress experienced by the animals, without losing the behavioural effects that formalin triggers.

We show that the use of an inhalable anaesthetic during the time of formalin administration minimises animal stress and improves injection consistency. Whilst the anaesthetic reduced the behaviours observed during the first response phase, it appears not to affect the responses observed during the second phase of the test. We validated our proposed method by showing its sensitivity to a known analgesic agent, gabapentin, as well as its efficacy in different transgenic mouse lines. Together, our data present a refined method for the formalin test, whilst also demonstrating that the second phase can occur without a behavioural response during the first phase.

\section{Methods}

Ethical statement

All experiments were performed in accordance with the UK Animals (Scientific Procedures) Act 1986 and Local Ethical Committee approval. All efforts were made to minimise the suffering of animals during the experiments by carefully following the procedures.

\section{Experimental animals}

In all experiments, adult (11 to 13 weeks of age) homozygous and wildtype, male and female littermates were used. For the gabapentin and sevoflurane experiments, wildtype C57BL/ 6 NTac mice were used. Studies on the anaesthetised groups were performed on animals bred at Mary Lyon Centre (MLC; Harwell, UK), whereas the remaining animals were bred at King's College London (KCL; UK). For the experiments using transgenic animals, mice carrying the null alleles Pink $1^{\text {tmlb(EUCOMM)Wtsi }}$ and Slit ${ }^{\mathrm{tmlb(Komp)Wtsi}}$ were generated at Harwell (UK), as part of the International Mouse Phenotyping Consortium (IMPC) and maintained as heterozygotes on a C57BL/6NTac background. The colony was intercrossed and genotyped by an independent experimenter, to ensure effective blinding during behavioural testing. Males and females were used in the experiments (except for the Gabapentin study, Figure 3). No sex-difference in behavioural responses to the formalin test was found in this study. Details on both the visual representations and statistical analysis demonstrating no differences between the genders are presented on Supplementary Figure 1. The transgenic lines chosen in this study were part of a parallel neuroscience program study being carried out at the MLC. In addition, it has been suggested a link between Pink1 and nociceptive processing 29,30 and Slit1 expression and peripheral injury ${ }^{31-36}$.

\section{Housing and husbandry}

Animals were housed in IVC cages (Tecniplast - 1284L and 1285L, with autoclaved Datesand Aspen bedding) in groups of 2 to 5 per cage, under 12-hour-on/12-hour-off cyclic lighting (30minutes dusk to dawn, dawn to dusk period), at controlled 
temperature $\left(21 \pm 2^{\circ} \mathrm{C}\right)$ and humidity $(55 \pm 10 \%)$ conditions. Cage bases were changed weekly. The mice had free access to filtered water (25 p.p.m. chloride) and were fed ad libitum on a commercial diet - either Rat and Mouse Diet No. 3 [RM3] (Special Diet Services, Essex, UK), composed of $5.3 \%$ fat [corn oil], $21.2 \%$ protein, $57.4 \%$ carbohydrate and $4.6 \%$ fibre (provided at the MLC; Harwell BSU facility), or PicoLab Rodent Diet 5053 (LabDiet St. Louis, MO, USA), composed of $21 \%$ protein, $4.5 \%$ fat and $6 \%$ fibre (provided at King's College London BSU facility). All mice housed in the same facility received the same food. Food was irradiated to 2.5 Mrads. All mice went through daily health checks for general physical and health appearance (e.g. coat, eyes and ears appearances, fighting wounds), bedding/water bottle appearance and any signs of distress. The MLC and KCL are specific pathogen free centres.

\section{Sample size and allocation to experimental groups}

A total of 95 mice were used for the experiments: Sevoflurane experiments: $\mathrm{N}=16$ anaesthetised and $\mathrm{N}=8$ non-anaesthetised; Gabapentin experiments: $\mathrm{N}=20$ gabapentin and $\mathrm{N}=16$ controls; Pink1 experiments: $N=8$ Pink1 $-/-$ and $N=5$ controls and Slit1 experiments :N = 11 Slit1 -/- and N = 11 controls. Animals were allocated using simple random randomization, i.e. subjects to each group purely randomly for every assignment.

\section{Experimental procedure}

Mice were anaesthetised by inhalation of sevoflurane $(5 \%$ flow) (Zoetis, UK) for 2 minutes, followed by subcutaneous injection of formalin (20ul at $1.85 \%$ concentration) (Sigma, $\mathrm{UK}$, Cat $\mathrm{N}^{\circ}$ 252549) into the right hind paw. A 30-gauge needle was used to perform the injections. A single animal was then placed into the arena (details below, and in Figure 1) and camera recording was started. For the gabapentin experiments (experiments related to Figure 3), gabapentin (Sigma, UK, Cat. № G154) was injected intraperitoneally at a concentration of
$50 \mathrm{mg} / \mathrm{kg}$, immediately prior to the injection of formalin. All experiments were performed during the light cycle (usual starting time 9am).

Perspex acrylic glass arenas $(36 \times 40 \times 13 \mathrm{~cm})$, consisting of three mirrored and one transparent wall, were built in house (please refer to the apparatus set up in Figure 1). A recording camera was positioned to face the arena, at an approximate $30^{\circ}$ angle to the surface on which the arena is placed and $50 \mathrm{~cm}$ away from the transparent wall, so all mouse behaviour could be easily recorded for later analysis. The set-up also allows annotations to be made by independent experimenters to provide accurate and reproducible observations of the changes in behaviour. Pain behaviour was scored using a stopwatch when flinching, licking and flinching continued by licking, flicking or shaking of the paw were initiated and timer was stopped once behaviour ceased. Limping, altered locomotion or grooming of other parts of the body were not counted as pain behaviours. The first phase of the test was designated as the time between zero and 15 minutes after the formalin injection, whereas the late (or second) phase was from 15 minutes onwards (up to 45 minutes). Animals were humanely culled using Schedule 1 at the end of the test. All experiments were annotated by an experimenter, blinded to the genotype and treatment.

\section{Statistical analysis}

Statistical analyses were performed using OriginLab 2017 software (Origin Group Corp.) (for area under the curve) and SPSS Statistics 20 (ANOVA repeated measures). For all sets of samples, normality tests were performed using the ShapiroWilk test, to check whether the data fitted in a Gaussian distribution $(95 \%$ confidence intervals). Power calculations were performed using the Columbia University Biomath Calculator, following the guidelines previously described ${ }^{37}$. For details on the power calculation for each individual experiment, please
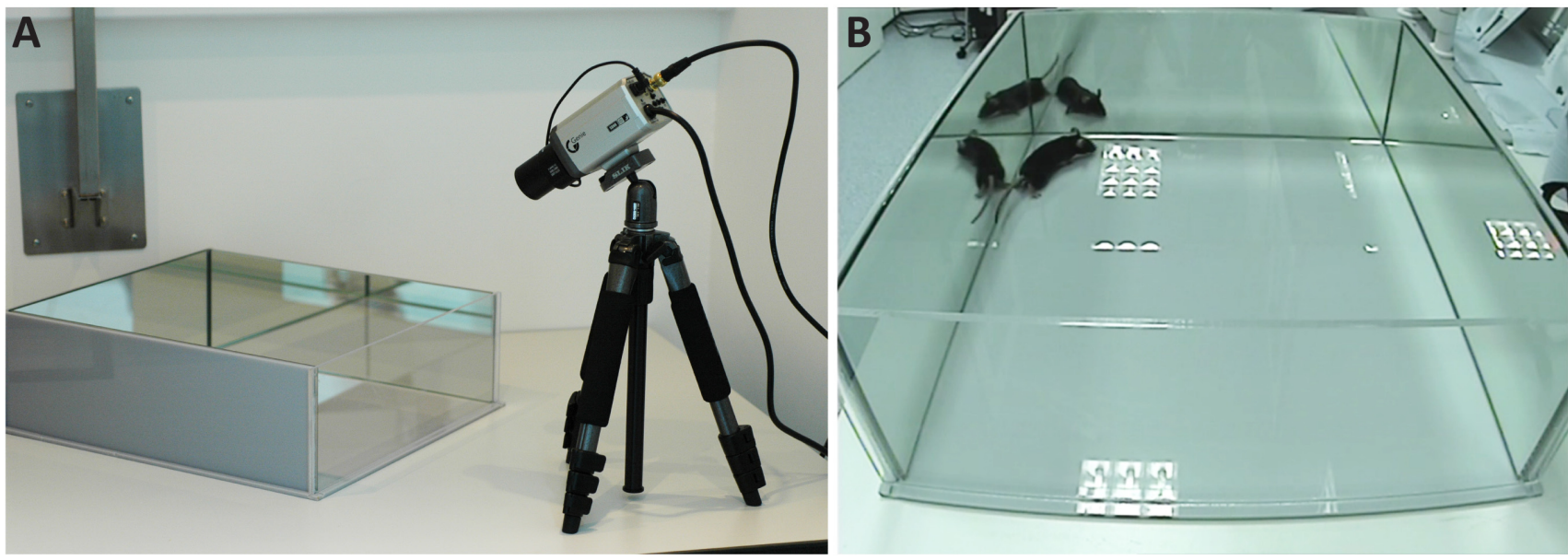

Figure 1. Formalin test apparatus. (a) Perspex acrylic glass arenas ( $36 \times 40 \times 13 \mathrm{~cm})$, consisting of three mirrored and one transparent wall, were used for the formalin test. The recording camera was placed facing the arena, at an approximate $30^{\circ}$ angle to the arena surface and $50 \mathrm{~cm}$ away from the transparent wall, so all mouse behaviour could be easily recorded for later analysis. (b) Video still of an experiment, showing that the behaviour of the animal could be meticulously monitored and accessed. 
refer to the Extended data section of this manuscript ${ }^{38}$ For all hypothesis testing, the minimum level of statistical significance adopted ( $\mathrm{p}$ value) was at 0.05 - where if there was a $5 \%$ or less chance ( 5 in 100 or less) against the null hypothesis, so the latter would be rejected. The AUC was calculated in relation to the pain response $(\mathrm{sec})$ over time.

\section{Results}

The formalin test is a robust model to study pain, and it has been demonstrated to be sensitive to various analgesic drugs $^{10,39-42}$. The stress and anxiety-like behaviours triggered by aversive handling and restraining of the animal whilst it is being injected with the formalin, together with exposure to an unfamiliar environment, may interfere with the stimulus and the outcome of the test ${ }^{43}$. To check whether restraining stress could be minimised during the formalin injection, without having a major effect on the results of the test, we anaesthetised the animals with sevoflurane at the time of injection. Our results show that the anaesthetic virtually abolished the first phase of the test, whilst still preserving the second phase (Figure 2a) ${ }^{38}$. When compared to non-anaesthetised mice, we observed a reduction in pain behaviour of approximately $90 \%$ (Figure $2 \mathrm{~b}$ ) for anaesthetised mice during the first 15 minutes of the test (first phase). Notably, no significant changes in behaviour following the injection of anaesthetised mice were observed during the late phase of the test (20 - 45 min after injection) when compared to the non-anaesthetised group (Figure $2 \mathrm{a} \& 2 \mathrm{~b}$ ).

The effect of the anti-epileptic drug gabapentin as an analgesic is well documented. Indeed, many studies demonstrate that
A

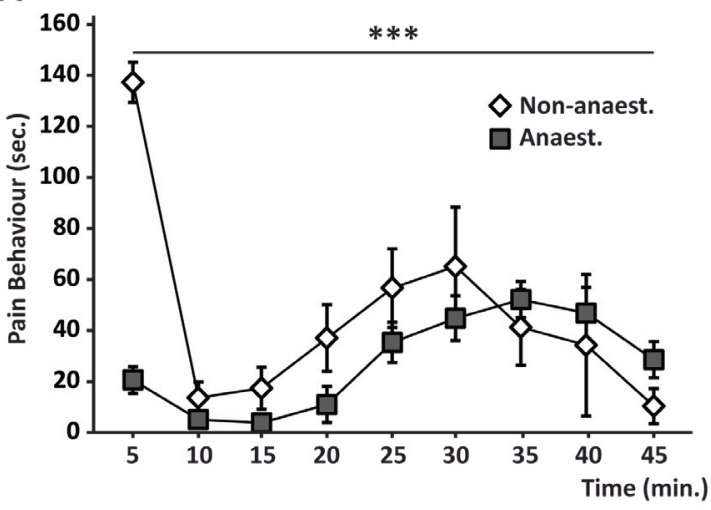

B

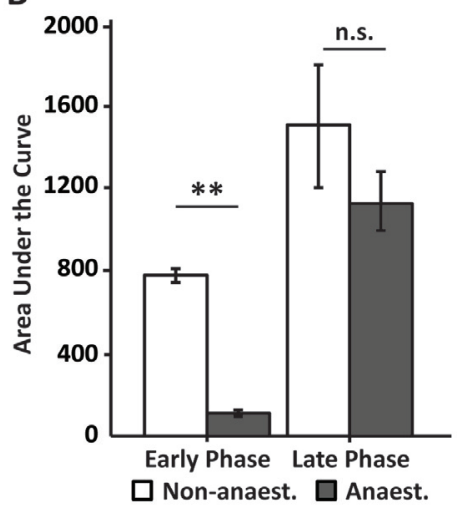

Figure 2. Sevoflurane during formalin injection only impacts on the first phase of the test. (a) Quantification of pain response over time of animals which were anaesthetised during the formalin injection (grey squares) and non-anaesthetised animals (white diamonds) shows distinct behaviors in the early phase of the test ( $0-15 \mathrm{~min}$. after injection) but similar behaviours in the later phase (15 minutes onwards). ANOVA repeated measures: time: $F_{(4,80)}: 5.92 ; p<0.001$; time ${ }^{*}$ group: $F_{(1,34)}: 5.357 ; p=0.001$. (b) Plots representing the area under the curve show a significant reduction in pain response in anaesthetised vs. non-anaesthetised animals during the early phase of the test, but not during the late phase ( $p<0.01$; One-way ANOVA; $N=16$ anaesthetised and $N=8$ non-anaesthetised). Graphs represent means $+/$ - SEM.

A

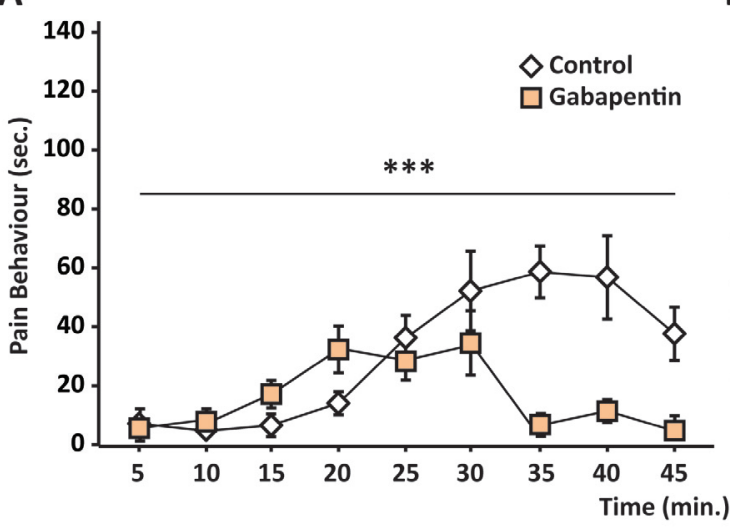

B

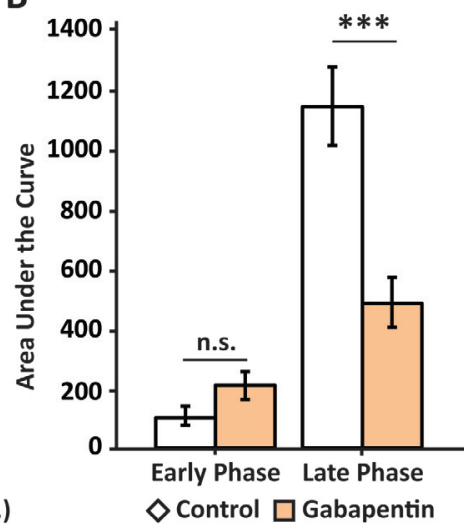

Figure 3. Use of anaesthetic does not interfere with gabapentin treatment. (a) Graph representing behavioural response to formalin injection over time. Anaesthetised animals which receive gabapentin (peach squares) present a diminished response to formalin injection in comparison to the control group (white diamonds; anaesthetic only). ANOVA repeated measures, time: $F_{(3.8,129.6)}: 7.998 ; p<0.001 ;$ time* ${ }^{*}$ roup: $F_{(3.8 .129 .634)}: 6.92 ; p<0.001$. (b) Bar graphs representing the area under the curve show no difference between the groups in the early phase of the test, but a clear effect of the drug during the late phase $(p<0.001$; One-way ANOVA; $N=20$ gabapentin and $N=16$ control). Graphs represent means +/- SEM. 
gabapentin attenuates nociceptive behaviour following formalin injection, specifically during the late phase of the test ${ }^{44-49}$. As the formalin test is widely used as a powerful tool to screen the analgesic effect of novel compounds at the preclinical level, we next tested whether gabapentin would also decrease the nociceptive behaviour observed after formalin injection using our newly proposed method. Our data demonstrate that in the gabapentin-treated group, there was a clear decrease in pain behaviour in the late phase of the test when compared to the control group (Figure 3a). Gabapentin treatment led to a reduction of over $50 \%$ in nociceptive behaviour after formalin injection (Figure 3b) in comparison with the non-treated group.

The use of transgenic animals in research has been crucial in elucidating numerous biological mechanisms involved in both health and disease, including in the field of pain research. Given the importance of transgenic mice and the results of behavioural tests to screen potential molecular targets, we went on to investigate whether our refined formalin method could be effective for newly generated transgenic mouse lines. For these experiments, we used two knockout mouse lines in which the target genes are known to be expressed in the dorsal root ganglia $(\mathrm{DRG})^{50-52}$ and in spinal cord neurons ${ }^{53}$.

The PTEN-induced kinase 1 (Pinkl) gene has been extensively studied in the context of Parkinson's disease ${ }^{54,55}$ and has been also linked to nociceptive processing ${ }^{29,30}$. Our data show that animals lacking Pinkl have a significantly lower response to the formalin test (Figure 4a). Although the Pinkl knockout group appeared to be marginally more responsive during the first 5 minutes of the test, their overall response to formalin injection during the first phase was very similar to their control littermates (Figure 4b). In contrast, their nociceptive behaviour during the late phase was reduced by $40 \%$ in comparison to the behaviour of the control group (Figure 4b). It appears that, despite being less responsive to the formalin, the Pink1 knockout animals have a steadier response in the second phase when compared to the control littermates, with no obvious peak in the response over time (Figure 4a).

Following the same principle, we went on to screen a transgenic mouse line with a disrupted Slit Guidance Ligand 1 (Slit1) gene, using our refined formalin test. Slit1 is a secreted protein, which has been reported to be involved in DRG and spinal cord development, and previous studies have suggested a link between injury and increased Slit1 expression ${ }^{31-36}$. Our data show no overall difference in pain behaviour in the formalin test between the group with disrupted Slit1 function and their control littermates (Figure 5a). As with control mice, the pain behaviour during the first phase of the test is dramatically reduced due to the anaesthetic. Notably, a loss of function of the Slit1 gene did not lead to any change in the nociceptive behaviour during the late phase of the test (Figure 5a and 5b), as both groups spent a similar amount of time exhibiting pain behaviour (Figure $5 b$ ).

\section{Discussion}

In this study we proposed a modified and improved method for the formalin test. We showed that by anaesthetising the animal at the time of the injection reliable, robust and reproducible results are produced, whilst diminishing stress to the animals. Our newly proposed method showed that whilst the pain behaviour in the first phase was suppressed by the anaesthetic, the response in the late phase remained comparable to the control, non-anaesthetised group. Our results were validated by pharmacological suppression of the late phase with gabapentin. Furthermore, we demonstrate that this is a useful method to use while screening transgenic lines for changes in pain behaviour in response to formalin.
A

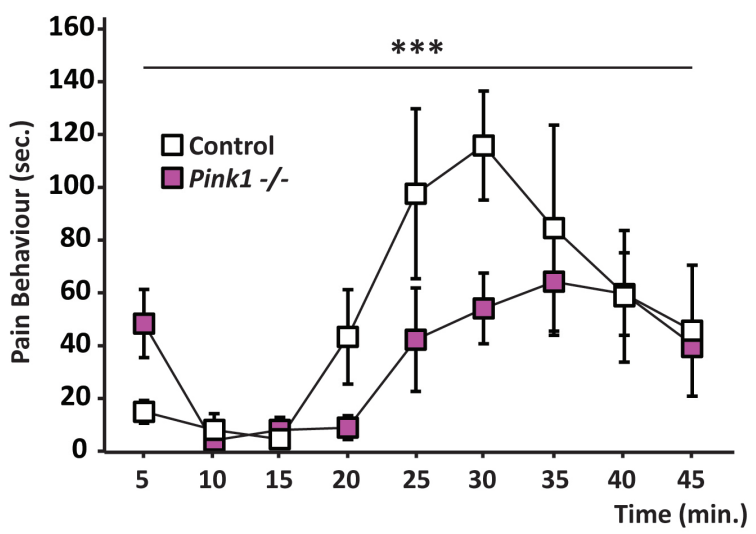

B

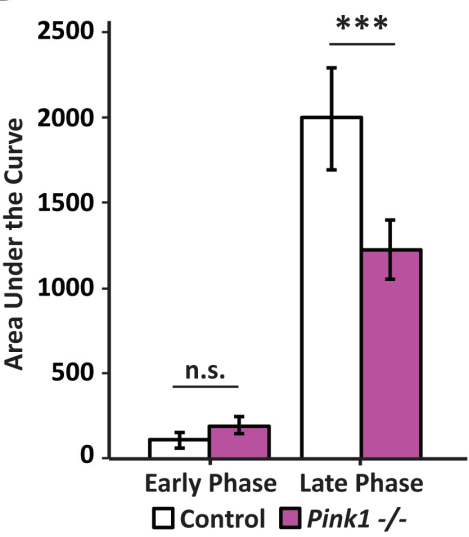

Figure 4. PTEN-induced kinase 1 knockouts (Pink1 -/-) present a distinct behaviour in the refined formalin test. (a) Graph showing the behavioural response of Pink1 -/- (pink squares) and their control littermates (white squares) over time. Pink1 -/- nociceptive behaviour in the late phase is reduced in comparison to the control group. ANOVA repeated measures, time: $F_{(3.84 .5)}: 6.772 ; p<0.001$. (b) Area under the curve plot shows that whilst both groups have very similar response to formalin in the early phase of the test, Pink 1 -/- mice display a lower pain response to formalin in the late phase ( $\mathrm{p}<0.001$; One way ANOVA; $N=8$ Pink $1-/$ - and $N=5$ control). Graphs represent means +/- SEM. 
A

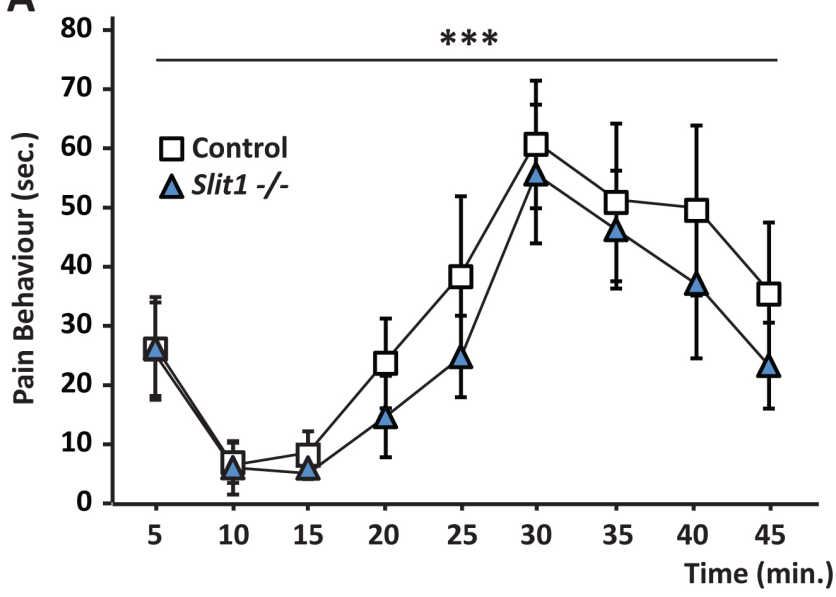

B

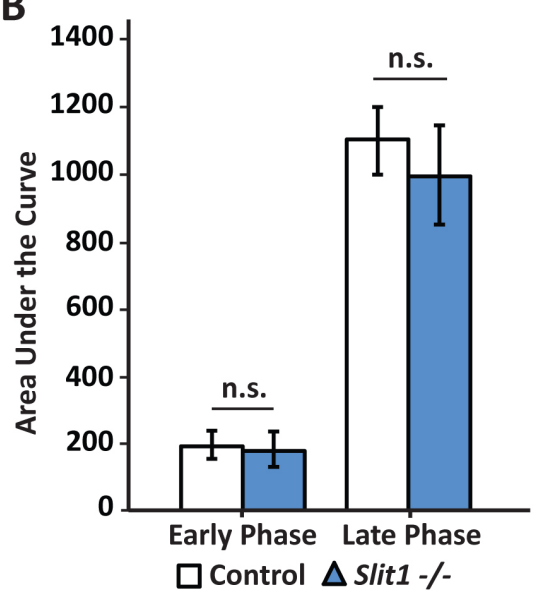

Figure 5. Slit1 knockout mice behave similarly to their control littermates in the refined formalin test. (a) Graphs depicting the behavioural response to formalin injection in Slit1 -/- (blue triangles) mice and control littermates (white squares). Both groups show similar pain behaviour in both phases of the formalin test. ANOVA repeated measures, time: $F_{(3.6,72.9)}: 0.928 ; p<0.001$. (b) Area under the curve graph further shows the similarities in pain behaviour between Slit1 -/- and control groups. (n.S., where p>0.05; One-way ANOVA; N = 11 Slit1 -/and $\mathrm{N}=11$ control). Graphs represent means +/- SEM.

Reducing the levels of stress in the animals is of great advantage when performing behaviour tests. Many studies have shown that mishandling of laboratory animals can have profound impacts on some behavioural tests ${ }^{43,56,57}$. In particular, animal restraining has a drastic, negative effect on anxiety levels ${ }^{58,59}$, with evidence suggesting that the adverse effects also extend to pain behaviour, where it can lead to areflexia, hyperalgesia and, in some cases, abnormal flinching ${ }^{60-64}$. Given the potential adverse effect that stress, resulting from either mishandling or restraining the animal during the administration of a drug or compounds, can have on pain behaviour, we propose the use of anaesthesia during the drug application. In our method, we show that animals can be injected with formalin without causing any apparent distress, whilst increasing the reproducibility of the test, as consistency in the site of injection as well as the volume injected is improved under anaesthesia. Indeed, due to ethical considerations, it has recently been suggested that brief anaesthesia immediately before injection would be beneficial for the animals, as well as increasing the accuracy of substance application, considering that the site of formalin injection is crucial $^{65}$. Importantly, we show that the outcome of the test is similar to that of the traditional method and that, despite the anaesthesia reducing the pain behaviour during first phase, the second phase behaviour times remained almost identical. Notably, our method has a significant advantage over a previous study which employed different inhalation anaesthetics, shown to have a negative impact on the early and late stages of the test ${ }^{66}$, suppressing the pain behaviour in both phases dramatically and being remarkably different to non-anaesthetised animals. In summary, our method resulted in minor changes to overall behaviour responses and provided significant advantages for ethical and stress-free animal handling.

Central sensitisation by formalin appears to be the most crucial aspect of the test when evaluating nocifensive behaviour.
The underlying mechanisms of the formalin test are not fully understood. Historical experimental data indicate that the behavioural response observed after the injection is solely due to the direct stimulation and activity of C-fibre nociceptors ${ }^{1,9,67}$, whereas subsequent studies suggest the involvement of $\mathrm{A} \delta$ and non-nociceptive $A \beta$-fibres ${ }^{68,69}$. Whilst there is still controversy regarding the circuitry and cellular and molecular mechanisms triggered by formalin, subjects which are beyond the scope of this study, we demonstrate that the second phase of the test can be used to screen pain behaviour independently of the first phase. Supporting our findings, studies showed that knockout or ablation of distinct nerve fibre populations in animal models resulted mostly in a reduction of the pain behaviour in the second phase of the test, while the first phase was not necessarily affected ${ }^{69-71}$. Furthermore, these studies show that, in all instances in which the first phase is affected, the second phase will also be influenced ${ }^{69-71}$, demonstrating therefore that suppressing or diminishing the pain behaviour during the first phase of the test is almost inconsequential when screening phenotypes and testing drugs. Therefore, our study highlights that the formalin test could be improved by diminishing unnecessary animal distress without compromising the results, given that the first phase of the test is, in most cases, not very informative.

The second phase of the formalin test alone can be used for phenotypic screening. We confirmed the sensitivity of our modified protocol by showing that the effects of the extensively characterised analgesic, gabapentin ${ }^{44-48}$ are maintained as expected. We further validated the sensitivity of the modified formalin procedure in two different transgenic lines. The mitochondrial kinase Pinkl has been extensively studied, and mutations in this gene are notoriously linked to neuronal dysfunction in Parkinson's disease ${ }^{55,72-74}$. Previous studies also linked the loss of function of Pink1 in humans with abnormal pain sensation, where subjects present a higher mechanical and pressure threshold ${ }^{29,30}$. Notably, and similarly to the phenotype 
found in humans, we show here that animals with a disrupted Pink1 gene display lower nociceptive behaviour after formalin injection. However, it cannot be excluded, the hypoalgesic phenotype can be due to symptoms arising from Parkinson's disease itself - as Pink1-null mouse models might present motor dysfunction $^{75}$. Therefore, our results not only present for the first time a pain phenotype in a Pinkl-null rodent model in the context of the formalin test, but also supports the refinement of the proposed formalin method. It should be noted that control littermates for the Pinkl group showed a more pronounced response to the formalin in comparison to the other control groups. We trust the behaviour observed represents the natural variation it can be obtained when performing behavioural tests and therefore we can only emphasise the importance of having control littermates when performing these experiments. We hypothesise that there is not a biological obvious reason that can explain the variation observed apart from the fact that they are a different cohort of animals and thus likely to differ in experimenter, day and uncontrollable variances in their cage environment (e.g. genotype of parents). Further to the pain phenotype observed in the Pinkl knockout line, we also screened for any distinct phenotype observed for the Slitl knockout mice. Despite previous studies suggesting a role for Slit1 in neuronal development ${ }^{32,33,76}$, our data shows that global deletion of the gene does not lead to any alteration in pain behaviour in the formalin test. Together, these results demonstrate that the refined formalin test proposed in this study can be broadly used, not only to test the efficacy of drugs, as shown with gabapentin, but also to evaluate pain phenotypes in newly generated transgenic models.

In conclusion, in this study we present a refinement to the already established formalin test. We propose that the use of an inhalable anaesthetic during the injection of formalin is not only a reliable method to improve consistency when injecting the compound, but most importantly, represents a valuable refinement. We show that this method complies with the $3 \mathrm{Rs}$ sought by ethical committees, as well as meeting the additional 3Rs (relevancy, robustness and repeatability) sought by scientists $^{13}$. Moreover, we demonstrate that the test is sensitive enough to screen for possible pain phenotypes and suggest that diminishing the first phase of the formalin test has little consequence on the global pain response of the animal.

\section{Data availability}

Underlying data

Figshare: Lopes et al., A refinement to the formalin test in mice - Extended data. https://doi.org/10.6084/m9.figshare. 8230655.v3 $3^{38}$
This project contains the following extended data:

- Data Fig_2_Males Females.csv (raw data underlying Figure 2, including each animal's gender)

- Data Fig_3_Males Females.csv (raw data underlying Figure 3, including each animal's gender

- Data Fig_4_Males Females.csv (raw data underlying Figure 4, including each animal's gender

- Data_Fig_5_Males Females.csv (raw data underlying Figure 5, including each animal's gender)

- Data_Fig_2.csv (raw data underlying Figure 2)

- Data_Fig_3.csv (raw data underlying Figure 3)

- Data_Fig_4.csv (raw data underlying Figure 4)

- Data_Fig_5.csv (raw data underlying Figure 5)

Extended data

Figshare: Lopes et al., A refinement to the formalin test in mice - Extended data. https://doi.org/10.6084/m9.figshare. 8230655.v3 $3^{38}$

This project contains the following extended data:

- Supplementary Figure 1 (Graphs containing the distribution of males and females across the experiments).

- Lopes_et_al.,_2019_Power_Calculations.pdf (details of power calculations for each experiment)

Data are available under the terms of the Creative Commons Attribution 4.0 International license (CC-BY 4.0).

\section{Grant information}

This work was supported by the Wellcome Trust [102645]; Medical Research Council [53658, 53650].

The funders had no role in study design, data collection and analysis, decision to publish, or preparation of the manuscript.

\section{Acknowledgements}

We would like to thank Dr Franziska Denk for useful discussions of the data and advice on statistical analysis. We thank Dr Kim Chisholm and Dr Michelle Edye for the comments on the manuscript. This work was supported by the Wellcome Trust Program (102645/Z/13/Z). Mice were obtained from MRC Harwell with funding from the Medical Research Council for generating (53658) and phenotyping (53650), a member of the International Phenotyping Consortium (funding and further phenotypic information can be found at http://www. mousephenotype.org).
1. Dubuisson D, Dennis SG: The formalin test: a quantitative study of the analgesic effects of morphine, meperidine, and brain stem stimulation in rats and cats. Pain. 1977; 4(2): 161-74. PubMed Abstract | Publisher Full Text

2. Coderre TJ, Melzack R: The role of NMDA receptor-operated calcium channels in persistent nociception after formalin-induced tissue injury. J Neurosci. 1992;
12(9): 3671-5

PubMed Abstract | Publisher Full Text

3. Erami E, Azhdari-Zarmehri $\mathrm{H}$, Imoto $\mathrm{K}$, et al:: Characterization of Nociceptive Behaviors Induced by Formalin in the Glabrous and Hairy Skin of Rats. Basic Clin Neurosci. 2017; 8(1): 37-42.

PubMed Abstract | Publisher Full Text | Free Full Text 
4. Abbott FV, Franklin KB, Ludwick RJ, et al:: Apparent lack of tolerance in the formalin test suggests different mechanisms for morphine analgesia in different types of pain. Pharmacol Biochem Behav. 1981; 15(4): 637-40 PubMed Abstract | Publisher Full Text

5. Rosland $\mathrm{JH}$, Tjolsen $\mathrm{A}$, Maehle $\mathrm{B}$, et al:: The formalin test in mice: effect of formalin concentration. Pain. 1990; 42(2): 235-42. PubMed Abstract | Publisher Full Text

6. Sawynok J, Liu XJ: The Formalin test: characteristics and usefulness of the model. Rev Analg. 2004; 7(2): 145-163. Publisher Full Text

7. Tjolsen A, Berge OG, Hunskaar S, et al.: The formalin test: an evaluation of the method. Pain. 1992; 51(1): 5-17.

PubMed Abstract | Publisher Full Tex

8. Hole $\mathrm{K}$, Tjolsen $\mathrm{A}$ : The tail-flick and formalin tests in rodents: changes in skin temperature as a confounding factor. Pain. 1993; 53(3): 247-54. PubMed Abstract | Publisher Full Tex

9. Hunskaar S, Fasmer OB, Hole K: Formalin test in mice, a useful technique for evaluating mild analgesics. J Neurosci Methods. 1985; 14(1): 69-76. PubMed Abstract | Publisher Full Text

10. Hunskaar S, Hole K: The formalin test in mice: dissociation between inflammatory and non-inflammatory pain. Pain. 1987; 30(1): 103-14. PubMed Abstract | Publisher Full Text

11. Shibata M, Ohkubo T, Takahashi $\mathrm{H}$, et al:: Modified formalin test: characteristic biphasic pain response. Pain. 1989; 38(3): 347-52. PubMed Abstract | Publisher Full Text

12. Murray CW, Porreca F, Cowan A: Methodological refinements to the mouse paw formalin test. An animal model of tonic pain. J Pharmacol Methods. 1988; 20(2): 175-86.

PubMed Abstract | Publisher Full Text

13. Wells DJ: Animal welfare and the $3 R$ s in European biomedical research Ann NY Acad Sci. 2011; 1245: 14-6.

PubMed Abstract | Publisher Full Text

14. Uvarov O: Research with animals: requirement, responsibility, welfare. Lab Anim. 1985; 19(1): 51-75.

PubMed Abstract | Publisher Full Text

15. Parker RM, Browne $\mathrm{WJ}$ : The place of experimental design and statistics in the 3Rs. ILAR J. 2014; 55(3): 477-85. PubMed Abstract | Publisher Full Text

16. Russell WMS, Burch RL: The principles of humane experimental technique. London: Methuen \& Co., 1959

Reference Source

17. Sneddon LU, Halsey LG, Bury NR: Considering aspects of the 3 Rs principles within experimental animal biology. J Exp Biol. 2017; 220(Pt 17): 3007-3016. PubMed Abstract | Publisher Full Text

18. Resch M, Neels T, Tichy A, et al: Impact assessment of tail-vein injection in mice using a modified anaesthesia induction chamber versus a common restrainer without anaesthesia. Lab Anim. 2019: 53(2): 190-201. PubMed Abstract | Publisher Full Text

19. Kim JW, Ko MJ, Gonzales EL, et al.: Social support rescues acute stressinduced cognitive impairments by modulating ERK1/2 phosphorylation in adolescent mice. Sci Rep. 2018; 8(1): 12003. PubMled Abstract | Publisher Full Text | Free Full Text

20. Sutanto W, de Kloet ER: The use of various animal models in the study of stress and stress-related phenomena. Lab Anim. 1994; 28(4): 293-306. PubMed Abstract | Publisher Full Text

21. Kovacs LA, Schiessl JA, Nafz AE, et al: Both Basal and Acute Restraint StressInduced c-Fos Expression Is Influenced by Age in the Extended Amygdala and Brainstem Stress Centers in Male Rats. Front Aging Neurosci. 2018; 10: 248 PubMed Abstract | Publisher Full Text | Free Full Text

22. Schaefer DC, Asner IN, Seifert B, et al.: Analysis of physiological and behavioural parameters in mice after toe clipping as newborns. Lab Anim. 2010; 44(1): 7-13. PubMed Abstract | Publisher Full Text

23. Nohara M, Tohei A, Sato T, et al.: Evaluation of response to restraint stress by salivary corticosterone levels in adult male mice. J Vet Med Sci. 2016; 78(5): salivary

PubMed Abstract | Publisher Full Text | Free Full Text

24. Meijer MK, Spruijt BM, van Zutphen LF, et al:: Effect of restraint and injection methods on heart rate and body temperature in mice. Lab Anim. 2006; 40(4) 382-91.

PubMed Abstract | Publisher Full Text

25. Poole T: Happy animals make good science. Lab Anim. 1997; 31(2): 116-24. PubMed Abstract | Publisher Full Text

26. Jennings EM, Okine BN, Roche M, et al:: Stress-induced hyperalgesia. Prog Neurobiol. 2014: 121: 1-18. PubMed Abstract | Publisher Full Text

27. Porro CA, Carli G: Immobilization and restraint effects on pain reactions in animals. Pain. 1988; 32(3): 289-307. PubMed Abstract | Publisher Full Tex

28. Imbe H, Iwai-Liao Y, Senba E: Stress-induced hyperalgesia: animal models and putative mechanisms. Front Biosci. 2006; 11(1): 2179-92.

PubMed Abstract | Publisher Full Tex
29. Gierthmuhlen J, Lienau F, Maag R, et al: Somatosensory processing in a German family with PINK1 mutations: its potential role in Parkinson disease. J Neurol Neurosurg Psychiatry. 2009; 80(5): 571-574.

PubMed Abstract | Publisher Full Text

30. Ludwig J, Lienau F, Maag R, et al:: Abnormal somatosensory processing in PINK1 (PARK6) mutations carriers. Eur J Pain. 2006; 10(S1): S135. Publisher Full Text

31. Carr L, Parkinson DB, Dun XP: Expression patterns of Slit and Robo family members in adult mouse spinal cord and peripheral nervous system. PLOS One. 2017; 12(2): e0172736.

PubMed Abstract | Publisher Full Text | Free Full Text

32. Long H, Sabatier $\mathrm{C}, \mathrm{Ma} \mathrm{L}$, et al.: Conserved roles for Slit and Robo proteins in midline commissural axon guidance. Neuron. 2004; 42(2): 213-223. PubMed Abstract | Publisher Full Text

33. Mambetisaeva ET, Andrews W, Camurri L, et al.: Robo family of proteins exhibit differential expression in mouse spinal cord and Robo-Slit interaction is required for midline crossing in vertebrate spinal cord. Dev Dyn. 2005; 233(1): $41-51$.

PubMed Abstract | Publisher Full Text

34. Wehrle R, Camand E, Chedotal A, et al:: Expression of netrin-1, slit-1 and slit-3 but not of slit-2 after cerebellar and spinal cord lesions. Eur J Neurosci. 2005; 22(9): 2134-2144 PubMed Abstract | Publisher Full Tex

35. Yi XN, Zheng LF, Zhang JW, et al.: Dynamic changes in Robo2 and Slit1 expression in adult rat dorsal root ganglion and sciatic nerve after peripheral and central axonal injury. Neurosci Res. 2006; 56(3): 314-321. PubMed Abstract | Publisher Full Text

36. Zhang HY, Zheng LF, Yi XN, et al:: Slit1 promotes regenerative neurite outgrowth of adult dorsal root ganglion neurons in vitro via binding to the Robo receptor. J Chem Neuroanat. 2010; 39(4): 256-261.

PubMed Abstract | Publisher Full Text

37. Charan J, Kantharia ND: How to calculate sample size in animal studies? J Pharmacol Pharmacother. 2013; 4(4): 303-6.

PubMed Abstract | Publisher Full Text | Free Full Text

38. Lopes $\mathrm{D}$, Cater $\mathrm{H}$, Thakur M, et al.: Lopes et al., A refinement to the formalin test in mice - Extended data. 2019.

http://www.doi.org/10.6084/m9.figshare.8230655.v3

39. Afify EA, Alkreathy HM, Ali AS, et al.: Characterization of the Antinociceptive Mechanisms of Khat Extract (Catha edulis) in Mice. Front Neurol. 2017; 8: 69 . PubMed Abstract | Publisher Full Text | Free Full Text

40. Clarke PB, Franklin KB: Infusions of 6-hydroxydopamine into the nucleus accumbens abolish the analgesic effect of amphetamine but not of morphine in the formalin test. Brain Res. 1992; 580(1-2): 106-10. PubMed Abstract | Publisher Full Text

41. Damas J, Liegeois JF: The inflammatory reaction induced by formalin in the rat paw. Naunyn Schmiedebergs Arch Pharmacol. 1999; 359(3): 220-7. PubMed Abstract | Publisher Full Text

42. Taylor BK, Peterson MA, Roderick RE, et al:: Opioid inhibition of formalininduced changes in plasma extravasation and local blood flow in rats. Pain 2000; 84(2-3): 263-70.

PubMed Abstract | Publisher Full Text

43. Gouveia K, Hurst JL: Optimising reliability of mouse performance in behavioural testing: the major role of non-aversive handling. Sci Rep. 2017; 7: 44999. PubMed Abstract | Publisher Full Text | Free Full Text

44. Carlton SM, Zhou S: Attenuation of formalin-induced nociceptive behaviors following local peripheral injection of gabapentin. Pain. 1998; 76(1-2): 201-7. PubMed Abstract | Publisher Full Text

45. Field MJ, Oles RJ, Lewis AS, et al:: Gabapentin (neurontin) and S-(+)-3-isobutylgaba represent a novel class of selective antihyperalgesic agents. Br J Pharmacol. 1997; 121(8): 1513-22.

PubMed Abstract | Publisher Full Text | Free Full Text

46. Laughlin TM, Tram KV, Wilcox GL, et al.: Comparison of antiepileptic drugs tiagabine, lamotrigine, and gabapentin in mouse models of acute, prolonged, and chronic nociception. J Pharmacol Exp Ther. 2002; 302(3): 1168-75. PubMed Abstract | Publisher Full Text

47. Munro G: Pharmacological assessment of the rat formalin test utilizing the clinically used analgesic drugs gabapentin, lamotrigine, morphine, duloxetine, tramadol and ibuprofen: influence of low and high formalin concentrations. Eur J Pharmacol. 2009; 605(1-3): 95-102. PubMed Abstract | Publisher Full Text

48. Shimoyama N, Shimoyama M, Davis AM, et al: Spinal gabapentin is antinociceptive in the rat formalin test. Neurosci Lett. 1997: 222(1): 65-67. PubMed Abstract | Publisher Full Text

49. Salinas-Abarca AB, Avila-Rojas SH, Barragan-Iglesias $\mathrm{P}$, et al:: Formalin injection produces long-lasting hypersensitivity with characteristics of neuropathic pain. Eur J Pharmacol. 2017; 797: 83-93. PubMed Abstract | Publisher Full Text

50. Flegel C, Schöbel N, Altmuller J, et al.: RNA-Seq Analysis of Human Trigeminal and Dorsal Root Ganglia with a Focus on Chemoreceptors. PLoS One. 2015; 10(6): e0128951

PubMed Abstract | Publisher Full Text | Free Full Text

51. Thakur M, Crow M, Richards N, et al.: Defining the nociceptor transcriptome. Front Mol Neurosci. 2014; 7: 87.

PubMed Abstract | Publisher Full Text | Free Full Text 
52. Usoskin D, Furlan A, Islam S, et al:: Unbiased classification of sensory neuron types by large-scale single-cell RNA sequencing. Nat Neurosci. 2015; 18(1): 145-153.

PubMed Abstract | Publisher Full Text

53. Sakurai M, Kawamura T, Nishimura H, et al.: Induction of Parkinson diseaserelated proteins in motor neurons after transient spinal cord ischemia in rabbits. J Cereb Blood Flow Metab. 2009; 29(4): 752-758. PubMed Abstract | Publisher Full Text

54. Kawajiri S, Saiki S, Sato S, et al.: Genetic mutations and functions of PINK1. Trends Pharmacol Sci. 2011; 32(10): 573-580. PubMed Abstract | Publisher Full Text

55. Pickrell AM, Youle RJ: The roles of PINK1, parkin, and mitochondrial fidelity in Parkinson's disease. Neuron. 2015; 85(2): 257-273. PubMed Abstract | Publisher Full Text | Free Full Text

56. Deacon RM: Housing, husbandry and handling of rodents for behavioral experiments. Nat Protoc. 2006; 1(2): 936-946. PubMed Abstract | Publisher Full Text

57. Hurst JL, West RS: Taming anxiety in laboratory mice. Nat Methods. 2010; 7(10): 825-826.

PubMed Abstract | Publisher Full Text

58. Buynitsky T, Mostofsky DI: Restraint stress in biobehavioral research: Recent developments. Neurosci Biobehav Rev. 2009; 33(7): 1089-1098. PubMed Abstract | Publisher Full Text

59. Chiba S, Numakawa T, Ninomiya M, et al:: Chronic restraint stress causes anxiety- and depression-like behaviors, downregulates glucocorticoid receptor expression, and attenuates glutamate release induced by brain-derived neurotrophic factor in the prefrontal cortex. Prog Neuropsychopharmacol Biol Psychiatry. 2012; 39(1): 112-119. PubMed Abstract | Publisher Full Text

60. Fuchs PN, Melzack R: Restraint reduces formalin-test pain but the effect is not influenced by lesions of the hypothalamic paraventricular nucleus. Exp Neurol. 1996; 139(2): 299-305. PubMed Abstract | Publisher Full Text

61. King CD, Devine DP, Vierck CJ, et al.: Opioid modulation of reflex versus operan responses following stress in the rat. Neuroscience. 2007; 147(1): 174-182. PubMed Abstract | Publisher Full Text

62. King CD, Devine DP, Vierck CJ, et al:: Differential effects of stress on escape and reflex responses to nociceptive thermal stimuli in the rat. Brain Res. 2003, 987(2): 214-222.

PubMed Abstract | Publisher Full Text

63. Gameiro GH, Gameiro PH, Andrade Ada S, et al.: Nociception- and anxiety-like behavior in rats submitted to different periods of restraint stress. Physiol Behav. 2006; 87(4): 643-649.

PubMed Abstract | Publisher Full Text
64. Taylor BK, Peterson MA, Basbaum Al: Exaggerated cardiovascular and behavioral nociceptive responses to subcutaneous formalin in the spontaneously hypertensive rat. Neurosci Lett. 1995; 201(1): 9-12. PubMed Abstract | Publisher Full Text

65. Capone F, Aloisi AM: Refinement of pain evaluation techniques. The formalin test. Ann Ist Super Sanita. 2004; 40(2): 223-229. PubMed Abstract

66. Fukuda T, Nishimoto $\mathrm{C}$, Hisano $\mathrm{S}$, et al:: The analgesic effect of xenon on the formalin test in rats: a comparison with nitrous oxide. Anesth Analg. 2002 95(5): 1300-1304, table of contents.

PubMed Abstract | Publisher Full Text

67. Russell N, Heapy CG, Jamieson A: Afferent activity in models of inflammation. Pain. 1987; 30: S255. Publisher Full Text

68. Puig S, Sorkin LS: Formalin-evoked activity in identified primary afferent fibers: systemic lidocaine suppresses phase-2 activity. Pain. 1996; 64(2): 345-355. PubMed Abstract | Publisher Full Text

69. Shields SD, Cavanaugh DJ, Lee $\mathrm{H}$, et al.: Pain behavior in the formalin test persists after ablation of the great majority of C-fiber nociceptors. Pain. 2010; 151(2): 422-429.

PubMed Abstract | Publisher Full Text | Free Full Text

70. Macpherson LJ, Xiao B, Kwan KY, et al:: An ion channel essential for sensing chemical damage. J Neurosci. 2007; 27(42): 11412-11415.

PubMed Abstract | Publisher Full Text

71. McNamara CR, Mandel-Brehm J, Bautista DM, et al:: TRPA1 mediates formalininduced pain. Proc Natl Acad Sci U S A. 2007; 104(33): 13525-13530. PubMed Abstract | Publisher Full Text | Free Full Text

72. Mouton-Liger F, Jacoupy M, Corvol JC, et al.: PINK1/Parkin-Dependent Mitochondrial Surveillance: From Pleiotropy to Parkinson's Disease. Front Mol Neurosci. 2017; 10: 120.

PubMed Abstract | Publisher Full Text | Free Full Text

73. Przedborski S: The two-century journey of Parkinson disease research. Nat Rev Neurosci. 2017; 18(4): 251-259. PubMed Abstract | Publisher Full Tex

74. Scarffe LA, Stevens DA, Dawson VL, et al:: Parkin and PINK1: much more than mitophagy. Trends Neurosci. 2014; 37(6): 315-324. PubMed Abstract | Publisher Full Text | Free Full Text

75. Glasl L, Kloos K, Giesert F, et al:: Pink1-deficiency in mice impairs gait, olfaction and serotonergic innervation of the olfactory bulb. Exp Neurol. 2012; 235(1): 214-227. PubMed Abstract | Publisher Full Text

76. Marin O, Plump AS, Flames N, et al:: Directional guidance of interneuron migration to the cerebral cortex relies on subcortical Slit1/2-independent repulsion and cortical attraction. Development. 2003; 130(9): 1889-1901. PubMed Abstract | Publisher Full Text 


\section{Open Peer Review}

\section{Current Peer Review Status:}

\section{Version 2}

Reviewer Report 16 August 2019

https://doi.org/10.5256/f1000research.22123.r52019

(C) 2019 Bourbia N. This is an open access peer review report distributed under the terms of the Creative Commons Attribution License, which permits unrestricted use, distribution, and reproduction in any medium, provided the original work is properly cited.

\section{Nora Bourbia}

Public Health England, Chilton, UK

Thank you for revisiting your manuscript and replying to the reviewer questions.

It is unfortunate that you can't repeat the experiment but you do have a valid reason as well as you have given a response about the specific control group results.

Thank you for testing sex differences and adding the information on the supplementary data. However, you should use the word sex and not gender.

Competing Interests: No competing interests were disclosed.

Reviewer Expertise: I have done a PhD in neurophysiology of pain using rat model of chronic pain, followed by a postdoc in neurobehavioral genetics using mouse models. I am now a newPI in neurobiology.

I confirm that I have read this submission and believe that I have an appropriate level of expertise to confirm that it is of an acceptable scientific standard.

\section{Version 1}

Reviewer Report 22 July 2019

\section{https://doi.org/10.5256/f1000research.20060.r50152}

(C) 2019 Riddell J et al. This is an open access peer review report distributed under the terms of the Creative Commons Attribution License, which permits unrestricted use, distribution, and reproduction in any medium, provided the original work is properly cited.

John Riddell 
Spinal Cord Group, Institute of Neuroscience and Psychology, College of Medical, Veterinary and Life Sciences, University of Glasgow, Glasgow, UK

\section{Andrew Todd}

Spinal Cord Group, Institute of Neuroscience and Psychology, College of Medical, Veterinary and Life Sciences, University of Glasgow, Glasgow, UK

In this article, the authors demonstrate a refinement of the widely-used formalin test. They show that if the formalin injection is performed while mice are under brief general anaesthesia (Sevoflurane) the second phase behaviour is largely unaltered, even though the first phase behaviour is largely lost. Since the second phase is the more useful measure, this means that the procedure can be performed in a less stressful way, resulting in a significant improvement in animal welfare.

The results of the study are generally convincing, and the article is clearly written and well illustrated. One concern is the relatively high level of pain behaviour in the control group for the Pink1 study (Fig 4). While the area under the curve for other groups is typically around 1000, for the controls in Fig 4 it is nearly 2000. In fact, compared to other cohorts, the Pink1-/- mice seem to have normal behaviour, while the control group show an exaggerated response. Some explanation is needed here. Also - what are the units for area under curve?

Minor points:

It would be helpful to have some explanation of why the Pink1 and Slit1 mouse lines were chosen for this study, at the end of the Experimental Animals paragraph in the Methods section.

Page 4: In the $4^{\text {th }}$ line of the Results section "it is" should be inserted before "being" otherwise it would be the experimenter who received the injection.

Page 5: left column, $6^{\text {th }}$ line "led" rather than "lead".

Page 6: left column, $6^{\text {th }}$ line - omit "seem to".

Is the rationale for developing the new method (or application) clearly explained? Yes

Is the description of the method technically sound?

Yes

Are sufficient details provided to allow replication of the method development and its use by others?

Yes

If any results are presented, are all the source data underlying the results available to ensure full reproducibility?

Yes

Are the conclusions about the method and its performance adequately supported by the 
findings presented in the article?

Partly

Competing Interests: No competing interests were disclosed.

Reviewer Expertise: Animal models of pain, behavioral testing of pain-like behaviors, electrophysiology, dorsal horn circuit

We confirm that we have read this submission and believe that we have an appropriate level of expertise to confirm that it is of an acceptable scientific standard.

Author Response 30 Jul 2019

Douglas Lopes, King's College London SE1 1UL, London, UK

We would like to thank the reviewers for the very positive reviews of our paper. The reviewer's comments were very helpful, and we have now revised our manuscript to address all of the issues raised.

The results of the study are generally convincing, and the article is clearly written and well illustrated. One concern is the relatively high level of pain behaviour in the control group for the Pink1 study (Fig 4). While the area under the curve for other groups is typically around 1000, for the controls in Fig 4 it is nearly 2000. In fact, compared to other cohorts, the Pink1-/- mice seem to have normal behaviour, while the control group show an exaggerated response. Some explanation is needed here.

This point was was also raised by the other reviewer and addressed accordingly. We trust the behaviour observed represents the natural variation it can be obtained when performed behavioural tests and therefore we can only emphasise why it is important to control with animals that have been bred at the same time. Although we understand and acknowledge the reviewer's concerns, we trust the data is a true representation of the mice behaviour for this particular line. As demonstrated on the graph (Supplementary Figure $1 \mathrm{~B}$ ), all the control animals used in this test were above the average control response in the other figures (above $\sim 250 \mathrm{sec}$.), we therefore believe it is unlikely the findings are a false positive. We hypothesise that there is not a biological obvious reason that can explain this variation apart from the fact that they are a different batch of animals and thus likely to differ in experimenter, day and uncontrollable variances in their cage environment (such as genotype of parents, litters, litter size, etc.). Unfortunately, this line is no longer promptly available (it has been cryopreserved and archived) and therefore we are regrettably unable to repeat these experiments to investigate this further. We have however, added a sentence in the manuscript pointing out the differences observed and explaining it as above.

Also - what are the units for area under curve?

The AUC was calculated in relation to the pain response (sec) over time. This has been added to the materials and methods

Minor points: 
It would be helpful to have some explanation of why the Pink1 and Slit1 mouse lines were chosen for this study, at the end of the Experimental Animals paragraph in the Methods section.

These sentences were added: The transgenic lines chosen in this study were part of a parallel neuroscience program study being carried out at the MLC. In addition, it has been suggested a link between Pink1 and nociceptive processing $(48,49)$ and Slit1 expression and peripheral injury (50-55).

Page 4: In the 4th line of the Results section "it is" should be inserted before "being" - otherwise it would be the experimenter who received the injection. This has been amended.

Page 5: left column, 6th line "led" rather than "lead". This has been amended.

Page 6: left column, 6th line - omit "seem to". This has been amended.

Competing Interests: The authors declare no competing interests

Reviewer Report 26 June 2019

https://doi.org/10.5256/f1000research.20060.r50153

(c) 2019 Bourbia N. This is an open access peer review report distributed under the terms of the Creative Commons Attribution License, which permits unrestricted use, distribution, and reproduction in any medium, provided the original work is properly cited.

\section{Nora Bourbia}

Public Health England, Chilton, UK

Douglas M Lopes et al. have addressed the question of whether it is possible to refine the formalin test without affecting the behavioural outcome important in pain research. They have shown that the use of anaesthesia (sevoflurane) at the injection time reduces the distress of the handling and formalin injection, and the behaviour associated to the first phase while conserving the behaviour associated to the late phase of the formalin injection test.

The experiment and the method are well performed, clear to follow for reproducibility and well designed to answer to the initial question.

The study mentioned that both female and male mice were used which is very valuable and important in research. However, and except if I have missed it, I am not aware of the presence of a statistical test performed to confirm the absence of a sex-difference in behavioural responses to the formalin test in this study because sex difference can be a factor influencing the pain perception. A clarification would be appreciated as well as the presence of the sex in the source data.

Additionally, it is mentioned that wildtype C57BL/6 mice were used for the gabapentin and sevoflurane experiments but without mentioning the exact background while it is clearly mentioned for the transgenic mouse study (C57BL/6NTac). Pain-like behaviour can be influenced by the mouse strains, also behavioural differences have been observed between C57BL/6N and 
C57BL/6 J mice. It would be valuable to mention the exact background for a full reproducibility.

The results of the sevoflurane effect, the gabapentin treatment, and Slit1 KO studies are very clear. I did, however, notice a discrepancy in the data from the control group of the Pink1-/- study compared to the control group in Slit-/- study (both C57BL/6Ntac background) and the wildtype C57BL/6 mice in the anaesthesia/gabapentin experiment. The average pain behaviour in the control mice of the Pink1-/- study is almost twice higher than all other group controls and the Pink1-/- mice between the time 20 and $35 \mathrm{~min}$. Could the authors provide a possible explanation about this discrepancy? This might lead to a potential false positive result of Pink1 effect in this study. Ideally, to confirm the effect of Pink1-/- on the behaviour induced by the formalin test, it would be appreciated to repeat this test (Pink1-/-vs its littermate control) with again randomisation and blinding.

Is the rationale for developing the new method (or application) clearly explained? Yes

Is the description of the method technically sound?

Yes

Are sufficient details provided to allow replication of the method development and its use by others?

Yes

If any results are presented, are all the source data underlying the results available to ensure full reproducibility?

Partly

Are the conclusions about the method and its performance adequately supported by the findings presented in the article?

Partly

Competing Interests: No competing interests were disclosed.

Reviewer Expertise: I have done a PhD in neurophysiology of pain using rat model of chronic pain, followed by a postdoc in neurobehavioral genetics using mouse models. I am now a newPI in neurobiology.

I confirm that I have read this submission and believe that I have an appropriate level of expertise to confirm that it is of an acceptable scientific standard, however I have significant reservations, as outlined above.

Author Response 30 Jul 2019

Douglas Lopes, King's College London SE1 1UL, London, UK

We would like to thank the reviewers for the very positive reviews of our paper. The reviewer's comments were very helpful, and we have now revised our manuscript to 
address all of the issues raised.

The study mentioned that both female and male mice were used which is very valuable and important in research. However, and except if I have missed it, I am not aware of the presence of a statistical test performed to confirm the absence of a sex-difference in behavioural responses to the formalin test in this study because sex difference can be a factor influencing the pain perception. A clarification would be appreciated as well as the presence of the sex in the source data. Thank you for pointing that out. We have now uploaded the files containing the required information. We have also conducted statistical tests comparing males and females across the different experiments (except for the experiments using gabapentin, where only males were used). Furthermore, we uploaded an additional figure where the graphs contain each individual animal (females in red circle and males in blue square). The figure legend contains the details for each one of the tests. Both the visual representations and statistical analysis demonstrate no differences between the genders. A sentence stating the above findings and link to the Supplementary Figure has been added to the Material and methods section (Experimental Animals).

It should be noted that although we performed the appropriate statistical test to compare sex-differences and observe no differences, for some of the groups analysed the outcome might be pursued as not 'scientifically meaningful', as the numbers of animals in each subgroup were below the ' $n$ ' number recommended by some recent published guidelines (Curtis, et al., 2018 Br J Pharmacol. Apr; 175(7): 987-993).

Additionally, it is mentioned that wildtype C57BL/6 mice were used for the gabapentin and sevoflurane experiments but without mentioning the exact background while it is clearly mentioned for the transgenic mouse study (C57BL/6NTac). Pain-like behaviour can be influenced by the mouse strains, also behavioural differences have been observed between C57BL/6N and C57BL/6J mice. It would be valuable to mention the exact background for a full reproducibility. The background has now been added (C57BL/6NTac).

The results of the sevoflurane effect, the gabapentin treatment, and Slit1 KO studies are very clear. I did, however, notice a discrepancy in the data from the control group of the Pink1-/-study compared to the control group in Slit-/- study (both C57BL/6Ntac background) and the wildtype C57BL/6 mice in the anaesthesia/gabapentin experiment. The average pain behaviour in the control mice of the Pink1-/- study is almost twice higher than all other group controls and the Pink1-/- mice between the time 20 and $35 \mathrm{~min}$. Could the authors provide a possible explanation about this discrepancy? This might lead to a potential false positive result of Pink 1 effect in this study. Ideally, to confirm the effect of Pink1-/- on the behaviour induced by the formalin test, it would be appreciated to repeat this test (Pink1-/-vs its littermate control) with again randomisation and blinding.

Thank you for pointing this out. We trust the behaviour observed represents the natural variation it can be obtained when performing behavioural tests and therefore we can only emphasise why it is important to control with animals that have been bred at the same time. Although we understand and acknowledge the reviewer's concerns, we trust the data is a true representation of the mice behaviour for this particular line. As demonstrated on the graph (Supplementary Figure 1 B), all the control animals used in this test were above the average control response in the other 
figures (above $\sim 250 \mathrm{sec}$.), we therefore believe it is unlikely the findings are a false positive. We hypothesise that there is not a biological obvious reason that can explain this variation apart from the fact that they are a different batch of animals and thus likely to differ in experimenter, day and uncontrollable variances in their cage environment (such as genotype of parents, litters, litter size, etc.). Unfortunately, this line is no longer promptly available (it has been cryopreserved and archived) and therefore we are regrettably unable to repeat these experiments to investigate this further. We have however, added a sentence in the manuscript pointing out the differences observed and explaining it as above.

Competing Interests: The authors declare no competing interests

The benefits of publishing with F1000Research:

- Your article is published within days, with no editorial bias

- You can publish traditional articles, null/negative results, case reports, data notes and more

- The peer review process is transparent and collaborative

- Your article is indexed in PubMed after passing peer review

- Dedicated customer support at every stage

For pre-submission enquiries, contact research@f1000.com 